\title{
Formation of ovarian follicular fluid may be due to the osmotic potential of large glycosaminoglycans and proteoglycans
}

\author{
Hannah G Clarke ${ }^{1,2}$, Sarah A Hope ${ }^{3}$, Sharon Byers ${ }^{4,5}$ and Raymond J Rodgers ${ }^{1}$ \\ ${ }^{1}$ Research Centre for Reproductive Health, Department of Obstetrics and Gynaecology, The University of Adelaide, \\ Adelaide, SA 5005, Australia ${ }^{2}$ Pest Animal Control Cooperative Research Centre, CSIRO Sustainable Ecosystems, \\ Canberra, ACT, Australia ${ }^{3}$ Cardiovascular Research Centre, Monash University, Clayton, Victoria, Australia \\ ${ }^{4}$ Department of Chemical Pathology, Adelaide Women's and Children's Hospital, Adelaide, SA, Australia and \\ ${ }^{5}$ Department of Paediatrics, The University of Adelaide, Adelaide, SA 5005, Australia
}

Correspondence should be addressed to R J Rodgers; Email: ray.rodgers@adelaide.edu.au

\begin{abstract}
During mammalian follicle development, a fluid-filled antrum develops in the avascular centre of the follicle. We investigated the hypothesis that follicular fluid contains osmotically-active molecules, sufficiently large so as to not freely escape the follicular fluid. Such molecules could generate an osmotic differential and thus recruit fluid from the surrounding vascularised stroma into the antrum. Follicular fluid was collected from bovine follicles classified histologically as healthy ( $n=4$ pools) or atretic $(n=4$ pools). Dialysis of the follicular fluid at $300 \mathrm{kDa}$ or $500 \mathrm{kDa}$ resulted in a reduction in colloid osmotic pressure of $35 \%$ and $60 \%$, respectively, in fluid from healthy follicles and $29 \%$ and $80 \%$ from atretic follicles. Digestion of follicular fluid with Streptomyces hyaluronidase, chondroitinase $\mathrm{ABC}$ or DNase 1 followed by dialysis resulted in reductions in osmotic pressure of $43 \%, 53 \%$ and $43 \%$ respectively for fluids from healthy follicles and $34 \%, 20 \%$ and $31 \%$ for atretic follicles. Digestion with collagenase $I$, proteinase $K$, heparanase 1 or keratanase had no significant effect on the osmotic pressure of follicular fluid of healthy follicles. Ion exchange and size exclusion, Western blotting and ELISA identified the proteoglycans versican and inter-alpha trypsin inhibitor and the glycosaminoglycan hyaluronan in follicular fluid. We conclude that these molecules or aggregates of them are of sufficient size to contribute to the osmotic potential of follicular fluid and thus recruit fluid into the follicular antrum. DNA may also contribute but it is probably not a component that is regulated for this role.
\end{abstract}

Reproduction (2006) 132 119-131

\section{Introduction}

Follicle growth is extremely important because only large follicles ( $>10 \mathrm{~mm}$ in bovine) ovulate. Growth of the follicle encompasses both replication of follicular cells and formation and expansion of a follicular antrum. In some species such as rodents, the major part of the ovulatory follicles is cellular but in other species with a physically large ovulatory follicle such as ovine, porcine, human and bovine, the major component is follicular fluid (estimated at $>95 \%$ in bovine (Rodgers et al. 2001)). Perhaps surprisingly, replication of granulosa cells and expansion of the follicular antrum appear not to be tightly or coordinately regulated (Rodgers et al. 2001). For instance, in one study of bovine antral follicles, the thickness of the membrana granulosa was not at all related to the follicular size, with an approximately fivefold spread of thickness of the membrana granulosa for each size of the follicle (van Wezel et al. 1999b).
This would not be an issue except that in vitro studies of follicular growth have focused almost entirely on the replication of granulosa cells. When those species are in vivo with physically large follicles, it is not the number of granulosa cells per se that is an indicator of follicular growth but rather the rapid expansion of the follicular antrum which heralds the development of a dominant follicle to the pre-ovulatory stage. This growth is monitored in vivo by ultrasonography.

Despite the importance of the formation of follicular fluid and expansion of the follicular antrum, there is a dearth of literature on these topics. We and other researchers consider that the fluid component of follicular fluid is originally derived from the vasculature in the surrounding thecal layers. However, the means by which the fluid accumulates at the centre of the follicle is not known. The cells of the membrana granulosa constitute a stratified epithelium; however, they lack a network of tight junctions between cells that occur in 
some other epithelia. Thus, it would not be possible to establish an osmotic gradient across the membrana granulosa using small molecules like sodium, such as that which occurs, for example, in the renal tubules. The composition of follicular fluid is similar to serum with respect to low molecular weight components with most electrolytes being at the same concentrations in fluid and serum (Shalgi et al. 1972). However, for increasing sizes above $100 \mathrm{kDa}$, plasma proteins are found at progressively lower concentrations than in plasma (Perloff et al. 1955, Keikhoffer et al. 1962, Manarang-Pangan \& Menge 1971, Shalgi et al. 1973, Andersen et al. 1976). This suggests that there is a diffuse nominal "blood-follicle barrier" at sizes $>100 \mathrm{kDa}$. This barrier probably exists at the level of the follicular basal lamina.

Thus, a potential osmotic gradient could be established across the membrana granulosa if the granulosa cells directionally secreted molecules of large molecular weight towards the centre of the follicle. This osmotic gradient could then be responsible for recruiting fluid to the centre of the follicle. The regulation of such large molecules could be the means by which follicular fluid and antrum formation and follicular growth are regulated. Some of these ideas have been suggested a few times in the earlier literature, but they have never been tested nor have the molecules involved been identified. Here, we show that follicular fluid can exert osmotic potential using molecules larger than $300 \mathrm{kDa}$. We use the term 'potential' rather than 'pressure'. Pressure is the net result of the production of osmotic molecules and their concentration. Thus, if their production is counter balanced by net movement of fluid into the follicle, no net gain in pressure can be measured, even if the production of such molecules was responsible for the recruitment of the fluid. In the current experiments, we are not monitoring pressure but rather identifying molecules whose production could be expected to generate osmotic forces during follicular growth.

\section{Materials and Methods}

\section{Materials}

Earle's balanced-salts (EBSS) (\#E6132), decorin sulphate, 2,2'-azino-di- (3-ethylbenzthioazoline-6-sulfonic acid) DEAE sephacel and CL-2B sepharose were obtained from Sigma Chemical Company, St Louis, MO. Enzyme suppliers were: Sigma Chemical Company for DNase 1 and heparanase 1; Seikagaku Corporation, Tokyo, Japan for Streptomyces hyaluronidase, chondroitinase $A B C$ and keratanase. Proteinase $\mathrm{K}$ was obtained from Boehringer Mannheim, Mannheim, Germany, and collagenase I from ICN Biomedicals, Seven Hills, NSW, Australia. Dr Tracey Brown, Department of Biochemistry, Monash University, Victoria, Australia kindly donated hyaluronic acid standards. Ten, 100, $300,500 \mathrm{kDa}$ membranes used in dialysis were purchased from Millipore Corporation, Bedford, USA. The colloid osmometer was a Gonotec 050 from Gonotec $\mathrm{GmbH}$, Berlin, Germany. SDS gels were from Gradipore, Frenchs Forest, NSW, Australia. Novex Tris Acetate gels, and EcoRI digested SPP-1 phage DNA marker (DMW-S1) were from Geneworks, Adelaide, Australia. Gel Code Blue, Super Signal chemiluminescence Western blotting kit and Bradford assay kit were from Pierce, Rockford, MA, USA, Stains-all from Bio-Rad laboratories, Hercules, CA, and uronic acid standards were from Sigma Chemical Company. Hybond $\mathrm{C}+$ and Hybond $\mathrm{P}$ (PVDF) membranes were from Amersham Pharmacia Biotech, Piscataway, NJ, USA. All other chemicals were reagent grade from Sigma Chemical Company. Biotinylated hyaluronan binding protein (Cat. \# 400763-1) was from Seikagaku America, MA, USA. Silenus laboratories, Victoria, Australia, supplied horseradish peroxidase labelled streptavidin.

\section{Antibodies}

The primary monoclonal antibodies used in proteoglycan identification by ELISA and Western blots are described below. Primary antibody directed toward 4-sulphated chondroitin sulphate/dermatan sulphate (2B6) (Caterson et al. 1985), 6-sulphated chondroitin sulphate/dermatan sulphate (3B3) (Caterson et al. 1985), were purchased from ICN and aggrecan (1C6) (Caterson et al. 1985), was purchased from Developmental Studies, Hybridoma Bank, The University of lowa, lowa City, IA, USA. Antibodies recognising bovine decorin (LF94) and bovine versican (GAG $\beta$, recognising the GAG $\beta$ domain present in splice variants V0 and V1) (Schmalfeldt et al. 1998) were obtained from Dr Larry Fisher, Bone Research Branch, National Institutes of Health, Bethesda, MD and Dr Dieter Zimmermann, Molecular Biology Laboratory, Department of Pathology, University of Zurich, Switzerland, respectively. The antibody recognising the heparan sulphate containing the proteoglycan perlecan (A76) was kindly donated by Dr Anne Underwood, formerly of CSIRO Molecular Science, North Ryde, NSW, Australia. The antibody recognising human inter- $\alpha$-trypsin inhibitor (\#A0301) (Salier et al. 1987) was from Dako, Glostrup, Denmark. Silenus laboratories, Victoria, Australia, supplied secondary antibodies, sheep anti-mouse IgG conjugated to horseradish peroxidase and goat antirabbit IgG conjugated to horseradish peroxidase were from Chemicon Australia, Victoria, Australia.

\section{Tissues}

Ovaries were collected from cycling animals of mixed breeds of Bos taurus from the local abattoir within $20 \mathrm{~min}$ of slaughter and placed into HEPES-buffered EBSS, pH 7.5, containing $10 \mathrm{mM}$ N-ethylmalemide, $5 \mathrm{mM}$ benzamidine, $0.5 \mathrm{mM}$ phenylmethylsulfonylfluoride, 
$1 \mu \mathrm{g} / \mathrm{ml}$ pepstatin A, $1 \mu \mathrm{g} / \mathrm{ml}$ leupeptin, $0.01 \mathrm{MEDTA}$ and $0.1 \%$ sodium azide. The animals were deemed to be cycling by observing healthy or regressing corpora lutea and were visually assessed as being non pregnant. The ovaries were then transported on ice to the laboratory.

\section{Follicular fluids}

Antral follicles $(n=171) 11-16 \mathrm{~mm}$ in diameter were isolated for the determination of osmotic pressure and proteoglycan characterisation. Follicular fluid $(440-1200 \mu \mathrm{l})$ was aspirated from follicles with a 23G hypodermic needle and a 1 or $2 \mathrm{ml}$ syringe within $2 \mathrm{~h}$ of slaughter. The ovaries and follicles remained on ice throughout the procedure. The fluid samples were centrifuged at 2000 r.p.m. for $30 \mathrm{~min}, 4^{\circ} \mathrm{C}$ to remove cellular debris and protease inhibitors $(5 \mathrm{mM}$ benzamidine, $0.5 \mathrm{mM}$ phenylmethylsulphonylfluoride, $1 \mu \mathrm{g} / \mathrm{ml}$ pepstatin A, $1 \mu \mathrm{g} / \mathrm{ml}$ leupeptin, $0.01 \mathrm{M}$ EDTA and $0.1 \%$ sodium azide) were added before storage at $-20^{\circ} \mathrm{C}$. The remaining follicle walls were then fixed in Bouin's solution and embedded in paraffin. Histological assessment of follicular health (Irving-Rodgers et al. 2001) was undertaken by light microscopy analysis of haematoxylin and eosin-stained $5 \mu \mathrm{m}$-thick sections using an Olympus BX50 microscope. On completion of the assessment of follicle health, fluid samples were pooled based on the health status of the follicle from which they were collected. Fluids collected from healthy follicles were termed healthy fluids and those from atretic follicles termed as atretic fluids. Each healthy pool comprised 10 follicles and each atretic pool 8 follicles, with 4 pools used for each health status (see below). Follicles in a range of sizes from 2 to $15 \mathrm{~mm}$ were isolated for the determination of inter- $\alpha$-trypsin inhibitor levels and their fluid harvested as above. In addition, a large pool of fluid from unclassified antral follicles of all sizes was collected as above for chromatography.

\section{Size exclusion by differential dialysis}

In order to determine the contribution of the macromolecular components in the aspirated fluids, the fluids were diluted 1 in 10 with EBSS, pH 7.5, and dialysed against distilled water in membranes of differing MW cut offs $(10,100,300,500 \mathrm{kDa})$ for $24 \mathrm{~h}$ at $4{ }^{\circ} \mathrm{C}$. Following dialysis, samples were freeze-dried before reconstitution to their pre-dialysis volumes with EBSS. An aliquot of this material was assessed by $10 \%$ SDS-PAGE according to the method of Laemmli (1970) to confirm the removal of appropriately sized molecules. The experiments were performed with EBSS in order to maintain physiological ionic composition.

\section{Enzyme digestions of follicular fluids}

To quantify the contribution of classes of molecules to the osmotic pressure of follicular fluid, samples were

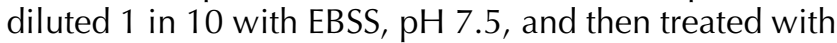
a range of enzymes (see Table 1 for details). Control pools of undigested fluid were held at $37^{\circ} \mathrm{C}$ or $25^{\circ} \mathrm{C}$ for $4 \mathrm{~h}$ whilst enzyme treatments were underway. Following this, digestion dialysis (100 kDa or $300 \mathrm{kDa}$ ) was carried out against $2 \mathrm{M} \mathrm{NaCl}$ solution, $24 \mathrm{~h}, 37^{\circ} \mathrm{C}$. Dialysis at high salt concentrations and temperature was necessary in this experiment to ensure removal of digested but potentially-aggregating molecules. All samples were then dialysed against distilled water for $24 \mathrm{~h}$ at $4{ }^{\circ} \mathrm{C}$. The samples were stored, freeze-dried and reconstituted to their original volumes in EBSS prior to measurement of osmotic pressure as described below. Once again, an aliquot of this material was assessed by SDS-PAGE to confirm the removal of appropriate molecules.

\section{Osmotic pressure estimations}

The colloid osmotic pressure was measured using a Gonotec 050 osmomat colloid osmometer with a reference membrane of $10 \mathrm{kDa} \mathrm{MW}$ cut-off. The reference solution was EBSS. All measurements of colloid osmotic pressure were recorded as $\mathrm{mm}$ of water pressure and repeated four times against $10 \mathrm{kDa}$ membrane at room temperature. Bovine serum (diluted 1:10 with EBSS) obtained from a non-pregnant cycling heifer was used as a control in each batch of measurements.

Table 1 Enzymes and digestion protocols used in digestion of specific molecular groups from follicular fluid.

\begin{tabular}{llll}
\hline Enzyme & Conditions & Source & Substrate \\
\hline DNase 1 & $5 \mathrm{mg} / \mathrm{ml}, 37^{\circ} \mathrm{C}, \mathrm{pH} 7.0$ & Sigma & DNA \\
Proteinase $\mathrm{K}$ & $0.1 \mathrm{mg} / \mathrm{ml}, 37^{\circ} \mathrm{C}, \mathrm{pH} 7.2$ & Boehringer & Protein \\
Streptomyces hyaluronidase & $7 \mathrm{U} / \mathrm{ml}, 37^{\circ} \mathrm{C}, \mathrm{pH} 7.2$ & Seikagaku & hyaluronan \\
Chondroitinase ABC & $1.0 \mathrm{U} / \mathrm{ml}, 37^{\circ} \mathrm{C}, \mathrm{pH} 8.0$ & Seikagaku & chondroitin sulphate/dermatan sulphate \\
Keratanase & $1.0 \mathrm{U} / \mathrm{ml}, 37^{\circ} \mathrm{C}, \mathrm{pH} 6.0$ & Seikagaku & KS \\
Collagenase I & $100 \mathrm{U} / \mathrm{ml}, 37^{\circ} \mathrm{C}, \mathrm{pH} 7.4$ & ICN & Collagen \\
Heparanase 1 & $1 \mathrm{U} / \mathrm{ml}, 25^{\circ} \mathrm{C}, \mathrm{pH} 7.5$ & Sigma & $\mathrm{HS}$ \\
No enzyme control 1 & $25^{\circ} \mathrm{C}, \mathrm{pH} 7.5$ & & \\
No enzyme control 2 & $37^{\circ} \mathrm{C}, \mathrm{pH} 7.2$ & & \\
\hline
\end{tabular}




\section{Ion-exchange and size exclusion chromatography}

Proteoglycans were isolated from a pool of follicular fluid from unclassified follicles by anion exchange chromatography on DEAE-Sephacel. Follicular fluid $(40 \mathrm{ml})$ was diluted 1 to 5 with $4 \mathrm{M}$ urea; $0.05 \mathrm{M}$ sodium

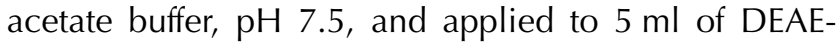
Sephacel at $4{ }^{\circ} \mathrm{C}$. The column was washed with 10 volumes of $4 \mathrm{M}$ urea in $0.05 \mathrm{M}$ sodium acetate buffer, $\mathrm{pH}$ 6.0. Proteoglycans were eluted from the column in the same buffer containing $2 \mathrm{M} \mathrm{NaCl}$. The fractions containing proteoglycans, as determined by uronic acid measurement, were pooled, dialysed against water and lyophilised. This sample was resuspended in $500 \mu \mathrm{l}$ of $2 \mathrm{M}$ guanidine- $\mathrm{HCl}, 0.1 \mathrm{M}$ sodium acetate, $0.05 \mathrm{M}$ Tris, $\mathrm{pH} 7.5$, and applied to a Sepharose CL-2B (6.5 mm $\times$ $1000 \mathrm{~mm}$ ) size exclusion column. Five hundred microliter fractions were collected, dialysed against $\mathrm{MQ}$ water and lyophilised for analysis of protein, glycosaminoglycans and proteoglycans.

\section{Protein and glycosaminoglycan measurements}

Protein concentrations were assayed by the Bradford method (Bradford, 1976). Gycosaminoglycan concentrations were determined by assaying the uronic acid concentration according to the method of Blumenkreuntz and Asboe-Hanson (Blumenkrantz \& Asboe-Hansen 1973, 1974).

\section{Proteoglycan ELISA}

The proteoglycan composition of the column fractions was determined by ELISA using a panel of antibodies specific to versican, decorin, aggrecan, perlecan and inter- $\alpha$-trypsin inhibitor and a general antibody to 4-sulphated chondroitin sulphate/dermatan sulphate. Samples analysed for 4-sulphated chondroitin sulphate/ dermatan sulphate or 6-sulphated chondroitin sulphate/dermatan sulphate required pre-digestion with chondroitinase ABC. Briefly, an aliquot of follicular fluid extracted from proteoglycans was treated with chond roitinase $\mathrm{ABC}(0.5$ units per $10 \mathrm{ml}$ in $0.1 \mathrm{M}$ Tris acetate buffer containing $0.1 \%$ bovine serum albumin, $\mathrm{pH} 8.0$ ) lyase to expose the antigen. Samples analysed for the presence of aggrecan using the 1C6 antibody required a reduction treatment with dL-dithiothrietol (DTT) prior to analysis. Following attachment to the wells, the samples were treated with $10 \mathrm{mM} \mathrm{DTT}\left(100{ }^{\circ} \mathrm{C} 10 \mathrm{~min}\right)$ and then alkylated with $20 \mathrm{mM}$ iodoacetic acid in the dark (2 h). Samples were treated in the same 96 well to which they had been previously attached and incubated for $1 \mathrm{~h}$ at $37^{\circ} \mathrm{C}$. Samples $(10 \mu \mathrm{l})$ to be tested were diluted in $140 \mu \mathrm{l}$ of phosphate-buffered saline (PBS, $137 \mathrm{mM} \mathrm{NaCl}$, $2.7 \mathrm{mM} \mathrm{KCl}, 10 \mathrm{mM} \mathrm{Na}{ }_{2} \mathrm{HPO}_{4}, 2 \mathrm{mM} \mathrm{KH_{2 }} \mathrm{PO}_{4}$ ) and incubated for $1 \mathrm{~h}$ at $37^{\circ} \mathrm{C}$ in 96-well plates (Nunc, \#430341). The wells were then rinsed in PBS/Tween
$20(0.05 \%)$ and incubated with $0.1 \mathrm{ml}$ PBS containing $1 \%$ skimmed cow's milk powder and the appropriate $d$ ilution of primary antibody [1:1000- for inter- $\alpha$-trypsin inhibitor (A0301), versican (GAG $\beta$ ), 4-sulphated chond roitin sulphate/dermatan sulphate (2B6), 6-sulphated chondroitin sulphate/dermatan sulphate (3B3) and aggrecan (1C6)] and incubated for $1 \mathrm{~h}$ at $37^{\circ} \mathrm{C}$. The secondary antibodies were sheep anti-mouse IgG conjugated to horse-radish peroxidase for the mouse monoclonal antibodies, and goat anti-rabbit conjugated to horse-radish peroxidase for the rabbit polyclonal antibodies, diluted at $1 / 2000-1 / 5000$ in PBS containing $1 \%$ skim milk powder and incubated for $1 \mathrm{~h}$ at $37^{\circ} \mathrm{C}$. Horse-radish peroxidase was measured as a color reaction using $100 \mu \mathrm{l}$ of 2,2'-azino-di-[3-ethylbenzthioazoline-6-sulfonic acid] as substrate with $0.01 \%$ hydrogen peroxide. The optical density was recorded at $415 \mathrm{~nm}$.

\section{Western and ligand blotting of proteoglycan components}

The proteoglycan component of follicular fluid was further characterised by electrophoresis on $0.8 \%$ agarose gels or $10 \%$ SDS-PAGE. The gels were then either stained with Stains-All or transferred to Hybond C + by capillary transfer in the case of the agarose gels or by electro transfer to PVDF for poly acrylamide gels (Towbin et al. 1979). Additionally, follicular fluids from follicles of increasing size of $2 \mathrm{~mm}-15 \mathrm{~mm}$ were examined for the presence of inter- $\alpha$-trypsin inhibitor by Western blotting. In all cases, the membranes were blocked in 5\% skim milk $\left(1 \mathrm{~h}\right.$ at $\left.37^{\circ} \mathrm{C}\right)$, washed $(3 \times \mathrm{PBS} / \mathrm{Tw}$ ween 20 for 5 min at room temperature), and incubated with an appropriate dilution of primary antibody directed against specific proteoglycan species as described above or with biotinylated hyaluronan binding protein $(0.5 \mu \mathrm{g} / \mathrm{ml})$, in $1 \%$ skim milk and incubated for $1 \mathrm{~h}$ at $37^{\circ} \mathrm{C}$. The membrane was washed $(3 \times$ PBS/Tween 20 for $5 \mathrm{~min}$ at room temperature) before incubation with an appropriate dilution of secondary antibody in $1 \%$ skim milk $(1 \mathrm{~h}$ at $37^{\circ} \mathrm{C}$ ) or streptavidin-horseradish peroxidase. The membrane was then rinsed $(3 \times$ PBS/Tween 20 for $5 \mathrm{~min}$ at room temperature) and the result visualised using either DAB or Super Signal Western blotting detection system according to the manufacturers protocol. Hyaluronan of sizes $220 \mathrm{kDa}, 860 \mathrm{kDa}$ and $1.6 \times 10^{6}$ Da were used as size indicators on agarose gels.

\section{DNA assay}

DNA components of the follicular fluid were resolved on $1 \%$ agarose gels in TAE buffer $(0.02 \mathrm{M}$ Tris, $0.5 \mathrm{mM}$ EDTA) and stained with either Stains-All or ethidium bromide. Prior digestion with proteinase K or RNase-free DNase $\left(1 \mathrm{mg} / \mathrm{ml}\right.$ for $1 \mathrm{~h}$ at $\left.37^{\circ} \mathrm{C}\right)$ was carried out to 
identify DNA and protein observed in these gels (Mandel-Gutfreund et al. 1995, Jones et al. 2001).

\section{Identification of collagenase sensitive molecules}

Following the digestion of the fluid samples with the enzymes mentioned above and subsequent PAGE analysis, it became apparent that there were significant differences in band profiles between the collagenasedigested fluid and undigested samples. In order to identify the components seen following the digestion step, we repeated the digest, isolated the bands of interest from the gel and extracted the proteins contained within the gel and then separated these on a 7\% Tris/acetate polyacrylamide gel. Excised bands were washed with 50\% methanol in water $(\mathrm{v} / \mathrm{v})$ and then dried in vacuo. They were subsequently rehydrated in a minimal volume of $2 \%$ SDS, $0.2 \mathrm{M}$ Tris- $\mathrm{HCl}, \mathrm{pH}$ 8.5. Ten volumes of water were added to the rehydrated gel pieces and PVDF membrane soaked with methanol was added to adsorb the diffusing proteins from the gel. Following complete transfer of the proteins to the PVDF, the membrane was washed five times in $0.5 \mathrm{ml} 10 \%$ methanol in water $(\mathrm{v} / \mathrm{v})$, dried and loaded into a reaction cartridge of an ABI PROCISE CLC protein sequencer followed by the identification of amino acids via HPLC. Peptide sequences were compared with mammalian databases using PROWL (http://prowl.rockefeller.edu) and those sequences with $>90 \%$ homology to a known protein were recorded in Table 2.

\section{Statistical analyses}

Statistical analyses were performed by one-way ANOVA with Bonferroni post-hoc tests using the Statistics Package for the Social Sciences (SPSS) software.

\section{Results}

Protein concentrations were $52 \pm$ s.E.M. $0.3 \mathrm{mg} / \mathrm{ml}$ in healthy fluid pools $(n=4)$ and $21.5 \pm 0.25 \mathrm{mg} / \mathrm{ml}$ in atretic pools $(n=4)$. To determine the contribution to the osmotic pressure in healthy and atretic follicular fluid of molecular components of different sizes, fluid was dialysed using a range of MW cut off membranes $(10,100,300$ or $500 \mathrm{kDa})$. Following dialysis, the osmotic pressure of the dialysed samples was measured using the $10 \mathrm{kDa}$ dialysate as the standard (Fig. 1). The osmotic pressures of the healthy (1:10 dilution, $2.45 \pm$ $0.45 \mathrm{~mm}$ water, $n=4)$ and atretic follicles $(2.35 \pm 0.40$, $n=4$ ) were similar. A non-significant reduction in osmotic pressure of approximately $35 \%$ and $29 \%$ was observed following dialysis of healthy and atretic fluids at $300 \mathrm{kDa}$ respectively. Dialysis against a $500 \mathrm{kDa}$ MW cut-off membrane resulted in a significant $60 \%$ reduction in osmotic pressure in fluid from healthy follicles and $80 \%$ reduction in fluid from atretic follicles. This clearly indicates that large molecular weight molecules or aggregates of molecules contribute significantly to the overall osmotic potential of follicular fluid of both healthy and atretic follicles.

\section{Specific enzyme digestion}

Specific components of follicular fluid were digested with the enzymes listed in Table 1, and the digested fluids dialysed against $100 \mathrm{kDa}$ or $300 \mathrm{kDa}$ MW cut-offs and the resultant osmotic pressure determined (Fig. 2). All digestion conditions resulted in some reduction of osmotic pressure of follicular fluid compared to the controls. Following dialysis against $100 \mathrm{kDa}$, results indicated that in fluid from healthy follicles, $43 \% \pm 6 \%$ of the pressure was significantly attributed to DNA, and $43 \% \pm 2 \%$ and $53 \% \pm 14 \%$ to hyaluronan and chondroitin sulphate/dermatan sulphate. In fluid from atretic follicles, $34 \% \pm 2 \%$ of the fluid pressure was contributed by DNA and $38 \% \pm 5 \%$ by collagen I sensitive molecules. Removal of heparan sulphate and keratan sulphate had no significant effect on osmotic pressure of either healthy or atretic fluid. The major difference between follicular fluid from healthy and atretic follicles

Table 2 Sequence identity of collagenase I sensitive proteins in follicular fluid.

\begin{tabular}{|c|c|c|c|c|c|}
\hline \multirow{2}{*}{ Band number* } & \multirow{2}{*}{$\begin{array}{l}\text { Peptide sequence } \\
\text { LPEREGAR }\end{array}$} & \multirow{2}{*}{$\begin{array}{l}\text { Homologous sequence } \\
\text { LPSIREGAR }\end{array}$} & \multicolumn{3}{|c|}{ Sequence identity $†$} \\
\hline & & & Secretin & Human & gi:107646 \\
\hline 4 & DQGVESPLF & EQGCESPLF & Hypothetical protein XP & Human & gi:75222627 \\
\hline \multirow[t]{3}{*}{5} & PTLVETAGR & PTLVELAGR & Serum albumin & Bovine & gi:229552 \\
\hline & LKQEPKAQR & LKQEKAQR & Involucrin & Human & gi:124723 \\
\hline & LTPSVKAGG & LTPSVKALG & $\begin{array}{l}\text { Agglutinin like protein } \\
\text { precursor } 3\end{array}$ & Human & gi:5902760 \\
\hline \multirow[t]{2}{*}{6} & DANTFLEAXR & RANTFLEEVR & Prothrombin precursor & Bovine & NP00497 \\
\hline & DANTFLEAXR & DANTFLEEXR & Coagulation factor $\mathrm{X}$ & Bovine & gi:119759 \\
\hline \multirow[t]{4}{*}{7} & RANTFLEAYR & RANTFLEEVR & Prothrombin precursor & Bovine & gi:135806 \\
\hline & DPGPPGLPAY & DPGPPGLPAY & Collagen IV alpha 2 & Human & gi:115349 \\
\hline & EPGPPPGALP & EPGPPPGLPAP & Collagen XIII alpha 1 & Human & gi:178320 \\
\hline & HVPEGLRVGE & HVPEGLRVGF & Alpha-2-macroglobulin & Human & gi:825615 \\
\hline
\end{tabular}

\footnotetext{
${ }^{*}$ Band numbers are identified in Fig. 7.

${ }^{+}$Sequence calls were made on the basis of the relative abundance of individual sequences and identified using PROWL (90\% similarity to mammalian sequences).
} 

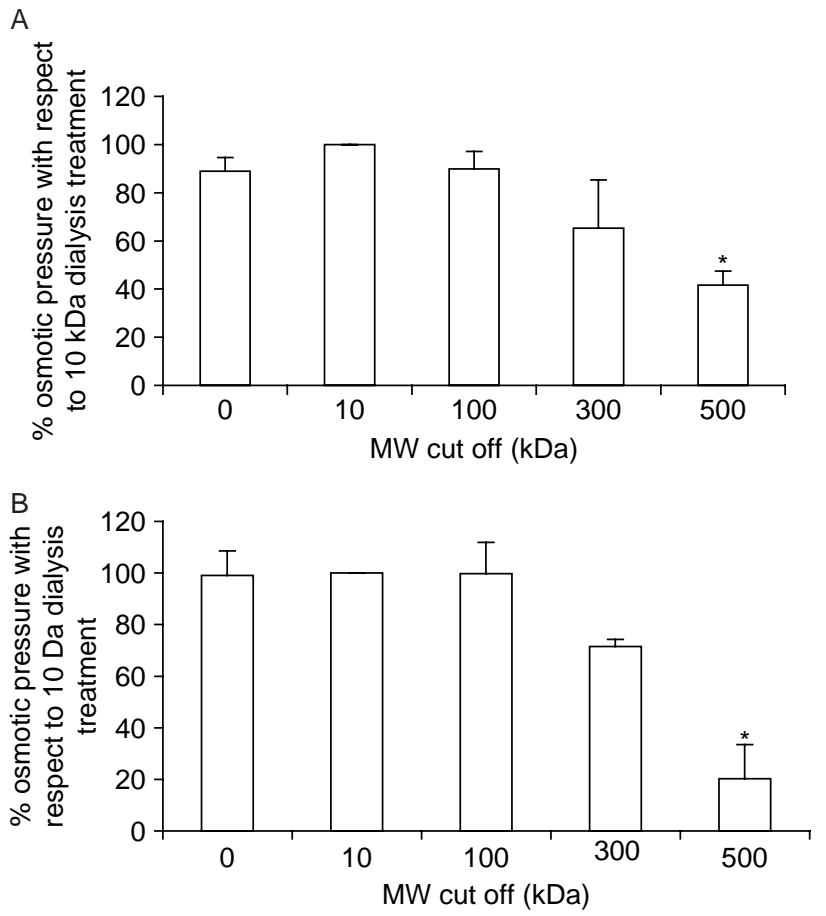

Figure $1 \mathrm{Effect}$ of the progressive removal of large molecules on the osmotic pressure of follicular fluid from healthy follicles (A) and atretic follicles (B). Osmotic pressure of 1:10 dilution of follicular fluid ( $10 \mathrm{kDa}=100 \%=2.45 \pm$ (s.E.M.) $0.45 \mathrm{~mm}$ water pressure for healthy follicles; $2.35 \pm 0.40$ for atretic follicles) versus the MW cut off of the dialysis membrane ( $n=4$ pools). ${ }^{*} P<0.05$ significantly from control (10 kDa).

was that hyaluronan and chondroitin sulphate/dermatan sulphate did not make a significant contribution to the osmotic pressure in atretic follicles.

Enzyme digestion and removal of a number of fluid components less than $300 \mathrm{kDa}$ reduced the osmotic

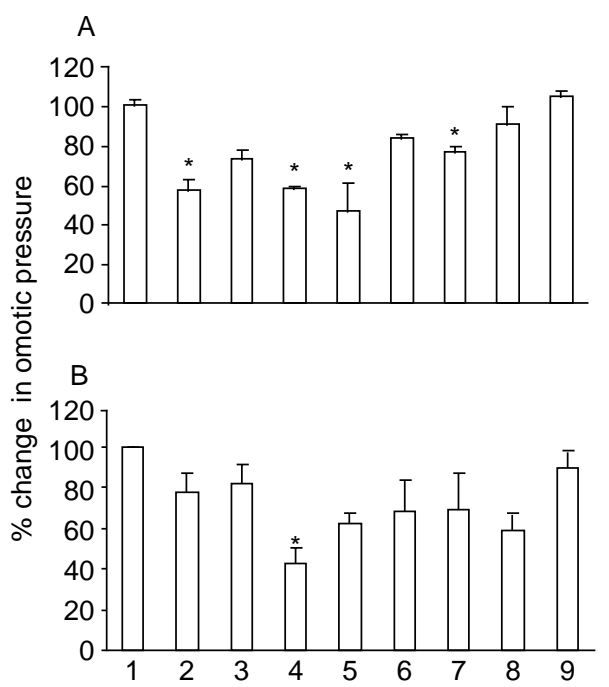

pressure in fluids from both healthy and atretic follicles (Fig. 2). In fluids from healthy follicles, $58 \% \pm 9 \%$ of the pressure was significantly attributed to hyaluronan. In fluid from atretic follicles, DNA contributed $51 \% \pm 2 \%$ of the pressure and hyaluronan contributed $57 \%$ with

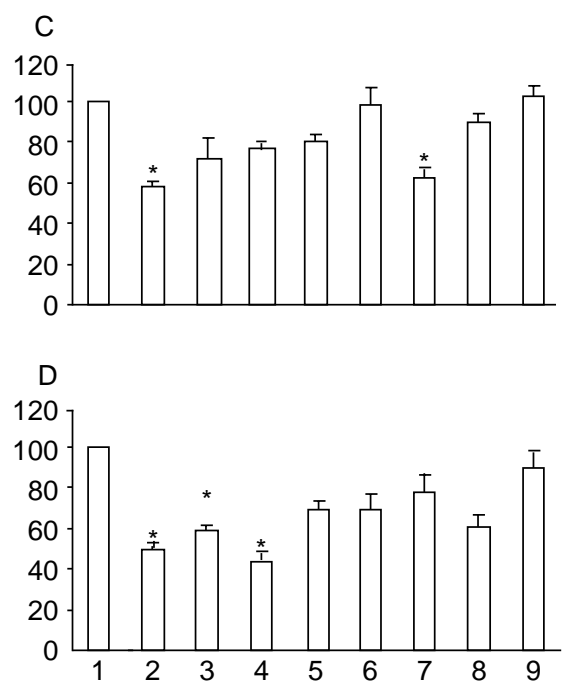

Figure 2 Effect of the removal of components by enzymatic digestion and dialysis at $100 \mathrm{kDa}(\mathrm{A}, \mathrm{C})$ or $300 \mathrm{kDa}(\mathrm{B}, \mathrm{D})$ of pools $(n=4 \mathrm{pools}$ for each) of follicular fluid from healthy (A, B) or atretic (C, D) follicles on osmotic pressure. The mean \pm s.E.M. osmotic pressure of the control (Lane $1=100 \%$ ) and the other treatments (Lane 2) DNase, (Lane 3) proteinase K, (Lane 4) Streptomyces hyaluronidase, (Lane 5) chondroitinase ABC, (Lane 6) keratanase, (Lane 7) collagenase I, (Lane 8) heparanase, or (Lane 9) bovine serum as listed in Table I (percentage changes in osmotic pressure are of a dilution of $1: 10$ dilution of follicular fluid $100 \mathrm{kDa}=100 \%=2.33 \pm 0.55 \mathrm{~mm}$ water pressure for the control of healthy follicles, $2.36 \pm 0.50 \mathrm{~mm}$ for atretic follicles; $300 \mathrm{kDa}=100 \%=1.6 \pm 0.07 \mathrm{~mm}$ water pressure for healthy follicles, $1.3 \pm 0.05 \mathrm{~mm}$ for atretic follicles).

$* P<0.05, * * P<0.01$ significantly different from control. 
protein contributing $32 \%$. Keratan sulphate removal had no significant effect on osmotic pressure of either healthy or atretic fluids.

\section{Glycosaminoglycans and proteoglycans in follicular fluid}

Proteoglycans in follicular fluid were isolated by anion exchange chromatography followed by size exclusion chromatography on Sepharose CL-2B. The concentration of protein, glycosaminoglycan, 4-sulphated chondroitin sulphate/dermatan sulphate and versican is shown in Fig. 3. No reactivity was detected against 6-sulphated chondroitin sulphate/dermatan sulphate (data not shown). The glycosaminoglycan poly-disperse peak overlapped that of the protein and the 4-sulphated chondroitin sulphate/dermatan sulphate overlapped that of the glycosaminoglycan peak (Fig. 3). Versican, a chondroitin sulphate proteoglycan, was detected in poly-disperse peak that overlapped the peak containing 4-sulphated chondroitin sulphate/dermatan sulphate. Confirmation of the presence of versican in follicular fluid samples was provided by Western immunoblot (Fig. 4) in which two immunoreactive bands were observed, probably corresponding to $\mathrm{V} 0$ and $\mathrm{V} 1$. Unpublished observations from RNA analyses confirm that both $\mathrm{V} 0$ and $\mathrm{V} 1$ are expressed in bovine follicles. Fractions from the size exclusion chromatography were treated with chondroitinase $\mathrm{ABC}$ and subjected to Western immunoblotting using an antibody to inter- $\alpha$-trypsin inhibitor (Fig 5A). Heavy chains and bikunin were identified, though the intensity of the bikunin band was weak as observed previously by others in other samples (Rouet et al. 1992). Since inter- $\alpha$-trypsin inhibitor was unexpected based upon reports in rodents (Chen et al. 1994), follicular fluid from a range of different sized follicles $(2 \mathrm{~mm}$ to $15 \mathrm{~mm}$ ) was examined and also found to contain inter- $\alpha$-trypsin inhibitor (Fig. 5B). Inter- $\alpha$-trypsin inhibitor and or related molecules, pre- $\alpha$ inhibitor and inter- $\alpha$ like inhibitor, were identified by Western blot analysis to be present in the fluid from all sizes of follicles examined. ELISA and Western blotting of the chromatography fractions did not detect perlecan, decorin or aggrecan (data not shown).

The pools of follicular fluid from healthy and atretic samples when separated on a $0.8 \%$ agarose gel and stained with Stains-All showed a smear of material from 500 bases to $>2 \times 10^{6}$ bases of DNA (data not shown). Immunoblotting of similar gels (Fig. 6) of this region showed that the majority of this smear was derived from versican, inter- $\alpha$-trypsin inhibitor and or its components and hyaluronan. The sizes of hyaluronan ranged from approximately $400 \mathrm{kDa}$ to $2 \times 10^{6} \mathrm{Da}$.
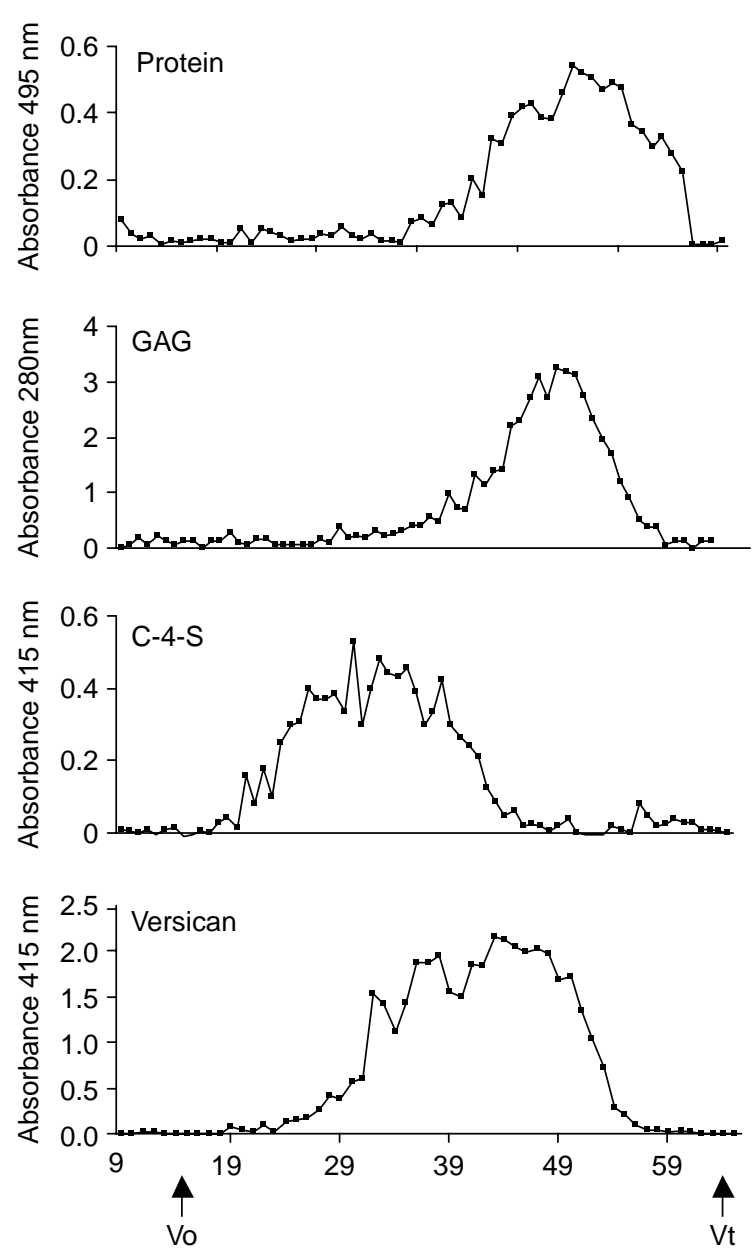

Figure 3 Size exclusion chromatography of proteoglycans isolated by anion-exchange chromatography. Proteoglycans isolated from a pool of follicular fluid by DEAE were chromatographed on CL-2B size exclusion column with $2 \mathrm{M}$ guanidine- $\mathrm{HCl}$ buffer. The eluted fractions were analysed for their concentrations of protein and GAG,

4-sulphated chondroitin sulphate/dermatan sulphate and versican.

\section{DNA content of follicular fluid}

Digestion of the follicular fluid samples with proteinase $\mathrm{K}$ or DNase and subsequent separation on agarose and staining with Stains-All (data not shown) or ethidium bromide (Fig. 7) demonstrated the presence of DNA in the fluid as well as the proteoglycans. The DNA of healthy follicular fluid ranged in size from 2799 bases to $>9000$ bases with some DNA remaining in the well, suggesting it is of a very large size $>2 \times 10^{6}$ bases. The DNA component of atretic follicular fluid, ranged from 500 bases to 9000 bases (data not shown).

\section{Identification of collagenase-sensitive components}

On digestion of the follicular fluids with collagenase I, some higher molecular weight proteins disappeared and new lower molecular weight molecules appeared as 


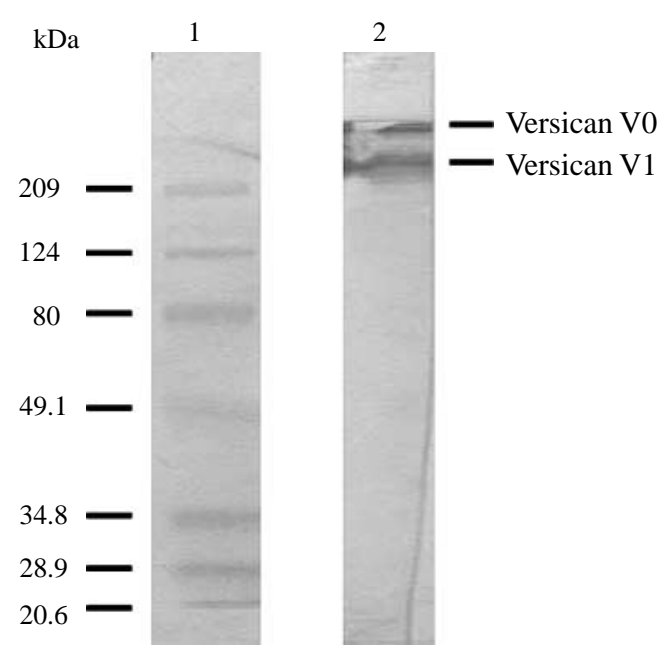

Figure 4 Western blot analysis of versican, lane 1, Broad range molecular weight marker, lane 2, follicular fluid was treated with chondroitinase $A B C$ and versican was visualised using the GAG $\beta$ antibody. Three microliters of pooled follicular fluid were loaded.

observed by PAGE (Fig. 8). Three major bands were seen following collagenase I digestion. To further resolve what clearly was a mixture of bands, the digest was separated on a $7 \%$ Tris-acetate gel after which nine bands were identified and taken for $\mathrm{N}$-terminal amino acid sequencing. Proteins identified in these bands and known to be collagenase sensitive are shown in Table 2. Several other sequences were identified as being present in the fluid samples; however, these were not known to be collagenase sensitive but are known constituents of serum and might therefore be expected in the follicular fluid.

\section{Discussion}

In this study, we have provided evidence of the presence of large osmotically active molecules in ovarian follicular fluid. To determine which classes of molecules contribute to the osmotic potential, we used enzymes to degrade these classes of molecules, followed by dialysis at MW cut offs at 100 and $300 \mathrm{kDa}$ to remove their digestion products. The protein concentration observed in the fluid from healthy follicles was more than twice that of the fluid from atretic follicles. Yet the total osmotic pressures were not significantly different. Results of the removal of fluid components of different molecular weights indicate however that significant differences in molecular constitution of fluid from healthy and atretic follicles do exist and these differences became apparent on determining the classes of molecules, contributing to the colloid osmotic pressure. Removal of the glycosaminoglycans, hyaluronan, chondroitin sulphate/dermatan sulphate, their aggregates and/or associated molecules, and DNA from follicular fluids of healthy follicles resulted in the greatest reduction in osmotic pressure at both MW cut offs. Removal of hyaluronan
A
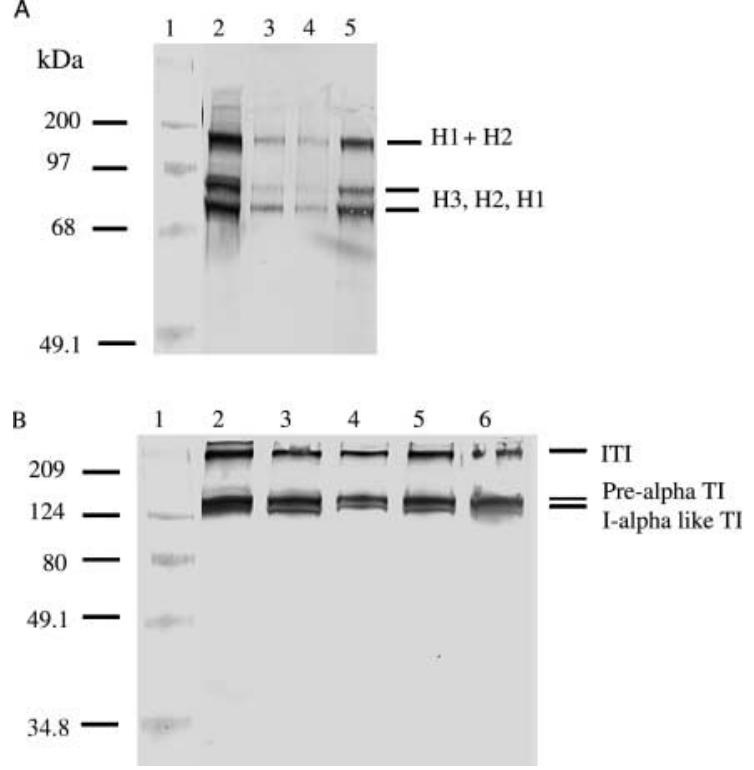

Figure 5 Western analysis of inter- $\boldsymbol{\alpha}$-trypsin inhibitor. (A) Follicular fluid was subjected to anion exchange and size exclusion chromatography, treated with chondroitinase ABC, separated by $10 \%$ SDS-PAGE and visualised using the rabbit anti-human inter- $\alpha$-trypsin inhibitor antibody. Molecular weight markers, lane 1; bovine serum, lane 2; fraction 28 from size exclusion column, lane 3; fraction 40, lane 4; fraction 52, lane 5 . Five microliters of fraction were loaded in each lane. Heavy chains $\mathrm{H} 1, \mathrm{H} 2$ or $\mathrm{H} 3$ and the $\mathrm{H} 1+\mathrm{H} 2$ complex bound by the chondroitinase $A B C$ resistant GAG bond are indicated based on a previous publication (Rouet et al. 1992). (B) Follicular fluid from follicles $(2-15 \mathrm{~mm}$ ) separated on a 10\% SDS-PAGE, under reducing conditions without prior chondroitinase $\mathrm{ABC}$ treatment, immunoblotted against inter- $\alpha$-trypsin inhibitor. Broad range marker; lane 1 , 2-5 mm, lane 2; 6-8 mm, lane 3; 9-10 mm, lane 4; 11-12 mm, lane 5; 13-15 mm, lane 6 . The native molecules are indicated (Rouet et al. 1992). Five microliters of sample was loaded in each lane. $\mathrm{H} 1, \mathrm{H} 2$ and $\mathrm{H} 3$ are heavy chains 1, 2 and 3 respectively, and pre-alpha $\mathrm{TI}$ and I-alpha like $\mathrm{TI}$ are pre- $\alpha$ trypsin inhibitor and inter- $\alpha$ like trypsin inhibitor, respectively.

and DNA from follicular fluid of atretic follicles made the greatest diminution in osmotic pressure at both $\mathrm{MW}$ cut offs, with contributions from proteins and collagenase I sensitive molecules. The results suggest that molecules in these classes contribute to the osmotic potential of follicular fluid. That glycosaminoglycans in follicular fluid exert osmotic activity is not surprising. Proteoglycans and their glycosaminoglycan side chains are thought to be partially responsible for the osmotic forces active during a number of fluid accumulation processes in the body (Comper \& Laurent 1978, Laurent 1987, Zamparo \& Comper 1989, Gu et al. 1993, Kovach 1995, Ishihara et al. 1997). Hyaluronan, chondriotin sulphate and dermatan sulphate are strongly hydrophilic and highly negatively charged and this negative charge is responsible for the osmotic activity of the molecules with which they are associated. Glycosaminoglycans have previously been identified in follicular fluid (Edwards 1974, Tadano \& Yamada 1978, Eppig \& Ward-Bailey 


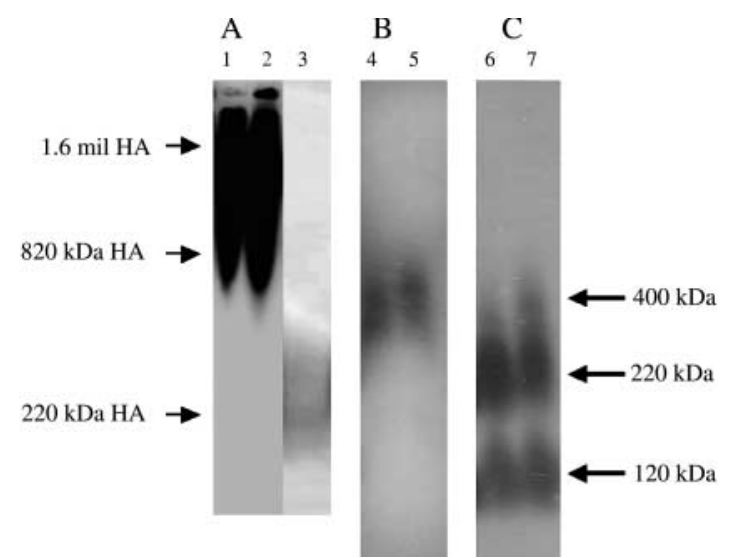

Figure 6 Follicular fluid separated by electrophoresis on nondenaturing agarose $(0.8 \%)$ gels and immunoblotted to identify hyaluronan, versican and inter- $\alpha$-trypsin inhibitor. (A) hyaluronan was visualised using biotinylated hyaluronan binding protein. (B) Versican (C) followed by re-probing for inter- $\alpha$-trypsin inhibitor. Lanes 1,4,6, follicular fluid from a pool of follicle $2-8 \mathrm{~mm}$; lanes $2,5,7$, follicular fluid from a pool of follicles $>10 \mathrm{~mm}$. Lane 3 follicular fluid digested with Streptomyces hyaluronidase. Three microliters of follicular fluid were loaded in each lane.

1984, Grimek et al. 1984, Reyes et al. 1984, Bushmeyer et al. 1985, Bellin et al. 1986, 1987, Bellin \& Ax 1987, Sato et al. 1987, 1988, Tsuiki et al. 1988, Vanderboom et al. 1989, Varner et al. 1991, Andrade-Gordon et al. 1992, Wise \& Maurer 1994, Boushehri et al. 1996, Parillo et al. 1998, Shimada et al. 2001) and this study demonstrates that they contribute to the osmotic potential of follicular fluid and are at sizes too large to leave the follicular antrum.

Hyaluronan has a variety of physiological functions in the extracellular matrix, such as rheological properties, flow resistance, osmotic pressure, exclusion properties and filter effects. Its osmotic effects provide a sensitive

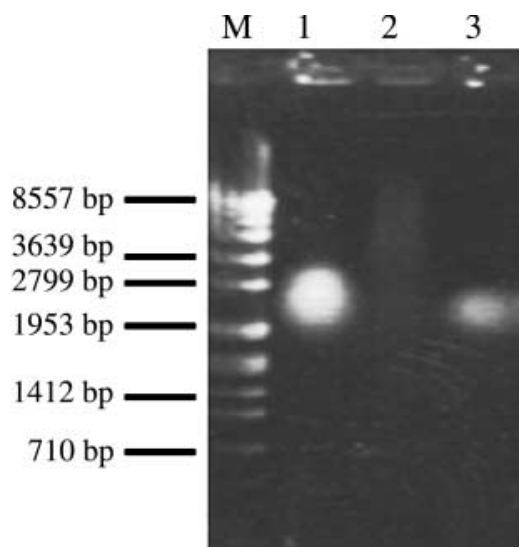

Figure 7 Pooled follicular fluid from uncharacterised follicles was separated by electrophoresis on non-denaturing agarose $(1 \%)$ gel and stained with ethidium bromide. Lanes 1-3 are follicular fluid treated with lane 1, no enzyme; lane 2, proteinase K; lane 3, DNase 1. EcoRI digested SPP-1 phage DNA marker, lane M. Three microliters were loaded in each lane.

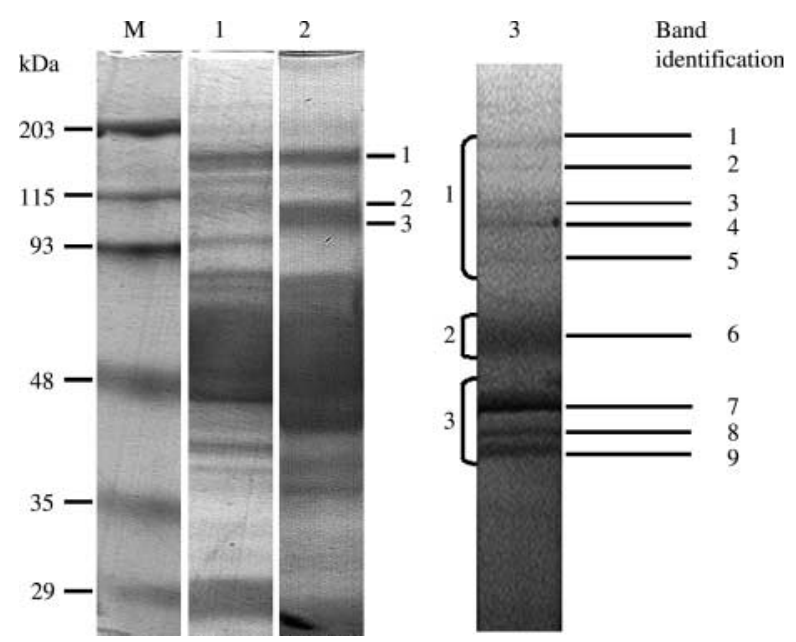

Figure 8 Isolation of collagenase I sensitive bands for $\mathrm{N}$-terminal sequence analyses. Five microliters of pooled follicular fluid from uncharacterised follicles before (lane 1) and after (lane 2) collagenase I digestion were separated by $10 \%$ SDS-PAGE. Three bands $(1,2,3)$ were identified in lane 2 as significantly different to the general profile obtained in the control lane 1 . These bands were resolved by Trisacetate PAGE (7\%) (lane 3). Bands removed for sequence identification are indicated on the right hand side of the Tris-acetate gel.

mechanism for volume buffering in the interstitium via the formation of highly entangled networks of flexible polysaccharide molecules (Rosengren et al. 2001). Hyaluronan is synthesised at the surface of cells by one of the three hyaluronan synthases (HAS1, 2 or 3) producing a repeating glycosaminoglycan chain of hyaluronic acid polymer, which extrudes into the extracellular space. Unlike proteoglycans, it does not have a core protein. However, there are a number of cell surface proteins (CD44, RRHAM and lyve-1) and other proteins (link protein, versican, inter- $\alpha$-trypsin inhibitor), which can bind to hyaluronan to form organised threedimensional matrices (Jackson 2003). In the ovary, hyaluronan production by cumulus cells has been extensively studied (Chen et al. 1993, 1996, Hirashima et al. 1997, Hess et al. 1999, Kobayashi et al. 1999). However, this production is tailored to release the oocyte and cumulus cell complex from the wall of the follicle into the fluid in preparation for ovulating this complex. For hyaluronan to be involved in follicular fluid formation, hyaluronan would need to be produced much earlier than that produced at ovulation by the cumulus-oocyte complex. In that regard, hyaluronan levels of human follicular fluid have been measured at $50.0 \pm 2.6 \mathrm{ng} / \mathrm{ml}$ and it has been previously localised adjacent to and including the spaces between antral granulosa cells (Saito et al. 2000). In addition, we observed hyaluronan in follicular fluids at sufficiently large sizes for it to be retained in the follicular antrum, and recently low levels of HAS 2 expression and hyaluronan production were observed in granulosa cells in culture (Schoenfelder \& Einspanier 2003). Thus 
clearly, hyaluronan has all the credentials to be a key player in the formation of follicular fluid.

Earlier research in a number of species has identified glycosaminoglycans, dermatan sulphate and chondroitin sulphate to be present in follicular fluids, and shown that glycosaminoglycans and proteoglycans are synthesised by the granulosa cells in vitro (Ax \& Ryan 1979, Bellin et al. 1983, Yanagishita et al. 1981, Eriksen et al. 1997). Here, we identified chondroitin 4-sulphated proteoglycans as significant contributors to the osmotic potential of follicular fluid. Using a combination of techniques, the proteoglycans identified in follicular fluid were versican and inter- $\alpha$-trypsin inhibitor. Decorin, perlecan and aggrecan were not detectable. Perlecan has been identified in extracts of whole bovine follicles (McArthur et al. 2000) and its RNA detected in granulosa cells (Princivalle et al. 2001, Irving-Rodgers et al. 2004). By immunohistochemistry, it was localised in the follicular basal lamina and focimatrix in large follicles (McArthur et al. 2000, Irving-Rodgers et al. 2004). It is not a component of follicular fluid. However, its presence in human follicular fluid has been reported (Eriksen et al. 1999), but in that study the fluid was aspirated at ovulation, a time when the follicular wall was being remodeled, allowing easy contamination of follicular fluid with the contents of the follicular wall. Hence, we do not consider that perlecan is a component of follicular fluid during follicle growth. Decorin has also been identified in extracts of whole follicles by us (McArthur et al. 2000), but we did not observe it here in follicular fluid. Localisation of decorin (unpublished observations) found it to reside outside the follicular basal lamina only. Hence, it is not a component of follicular fluid.

Versican is a chondriotin sulphate proteoglycan hyalectan with a broad tissue expression profile (Lemire et al. 2002). It has been shown to be present in extracts of bovine follicles (McArthur et al. 2000), follicular fluid of ovulating follicles (Eriksen et al. 1999), and in the follicular membrana granulosa (McArthur et al. 2000, Irving-Rodgers et al. 2004), and expressed by granulosa cells (Russell et al. 2003). It is involved in the expansion of the cumulus-oocyte complex (Camaioni et al. 1996, Carrette et al. 2001), whereby the heavy chains of inter$\alpha$-trypsin inhibitor become covalently cross-linked to hyaluronan, thereby stabilising the expanding cumulus matrix (Laurent et al. 1995, Eriksen et al. 1997, Saito et al. 2000, Carrette et al. 2001, Kimura et al. 2002). In addition to an N-terminal link-module hyaluronanbinding domain, versican possesses a C-terminal lectin-like domain that may bind cell surface or matrix molecules, and dual epidermal growth factor (EGF)-like modules. Many functional properties of versican are determined by two glycosaminoglycan attachment domains, which are modified to allow for attachment of long chondroitin sulphate side chains. These chains are responsible for versican's large molecular size and strong charge negativity and hence its osmotic properties. Versican may directly contribute to the osmotic potential of follicular fluid directly by virtue of the high sulphation status of chondroitin sulphate side chains attached to its core protein. However, versican may also contribute to the osmotic potential of follicular fluid by cross-linking other components like hyaluronan to form larger molecular weight components.

Inter- $\alpha$-trypsin inhibitor consists of two heavy chains linked by a chondroitin sulphate chain to bikunin and it is produced by the liver and is found abundantly in serum. In mice, inter- $\alpha$-trypsin inhibitor appears to be sequestered from the blood stream as it appears within the follicle fluid within minutes of the $\mathrm{LH}$ surge (Chen et al. 1992). On entering the fluid, it associates with hyaluronan being synthesised by the cumulus cells, liberating free bikunin and producing a covalent bond between the heavy chains and hyaluronan (Rugg et al. 2005). However, in bovine follicular fluid, we observed inter- $\alpha$-trypsin inhibitor (bikunin and its heavy chains) in normal follicular fluids. This is unlikely to be a contaminant from serum on collection of the follicular fluid, as we did not observe any contaminating perlecan or decorin in the samples. We detected inter- $\alpha$-trypsin inhibitor and related molecules in samples of fluid from follicles of $2 \mathrm{~mm}$ to $15 \mathrm{~mm}$ by Western analysis. These data are contrary to that previously published for the mouse ovary and the presence of inter- $\alpha$-trypsin inhibitor in follicles of a non-ovulatory size indicates that inter- $\alpha$ trypsin inhibitor may have additional roles in the bovine ovary. The recent discovery of inter- $\alpha$-trypsin inhibitor in follicular fluid from medium-sized porcine follicles indicates that the bovine is not the only species in which inter- $\alpha$-trypsin inhibitor is found in fluid prior to the LH surge (Nagyova et al. 2004). Its role in follicular fluid may be to bind to hyaluronan, cross-linking it to form larger aggregates, and thereby ensuring that hyaluronan does not escape the follicular antrum.

DNA was also found to exert osmotic potential, particularly in follicular fluids of atretic follicles. DNA in follicular fluid is likely to be derived from granulosa cells that align with the follicular antrum, which upon their death release DNA into the follicular fluid (Van Wezel et al. 1999a). These cells do not appear to die by classic apoptotic mechanisms but rather by a process with more in common to terminal differentiation (Van Wezel et al. 1999a). DNA may be entangled with larger molecules such as hyaluronan as suggested by several authors (Turner et al. 1988). This may increase the osmotic effect of the DNA by minimising the loss of DNA or hyaluronan from the follicular fluid. However, the DNA content of follicular fluid is probably not regulated and potentially it could easily be degraded by the release of cellular DNase. Thus DNA, whilst contributing to the osmotic potential of follicular fluid as observed here and possibly in vivo, is probably not a regulated component that contributes to the osmotic potential of follicular fluid. 
Another general means of formation of a cavity or lumen has not been discussed thus far. Cell death is important for formation of cavities or lumens as seen in blastocysts where the inner ectodermal cells undergo apoptosis to create a cavity (Coucouvanis \& Martin 1995, 1999) and for in vitro 'tube' formation (Meyer et al. 1997) or in vivo lumen formation by endothelial cells (Tertemiz et al. 2005). A role for any released DNA as means of providing osmotic pressure does not appear to be have been considered in these situations. Whilst it is unlikely in species with proportionally large follicular antra that cell death is a major cause of antrum formation, it is possible that such death plays a more substantive role in species with proportionally smaller follicular antra such as mice or rats. Certainly the difference in inter- $\alpha$-trypsin inhibitor between such species indicates potential differences between species in the way antra are formed.

Reduction in osmotic pressure by collagenase was interesting. Collagenase I used in the digestion of the fluid samples cleaves the helical strands of intact native collagen and degrades a number of other fibrillar proteins. We identified the following molecules: secretin, serum albumin, involucrin, agglutinin like protein precursor 3, coagulation factor $\mathrm{X}$, prothrombin precursor, collagen IV $\alpha 2$, collagen XIII $\alpha 1$, and $\alpha 2$ macroglobulin from digested fluid. However, from this screen, we did not identify any molecules that we believe would contribute to the regulated production of osmotic potential.

It is interesting to note that the overall reduction in osmotic potential caused by removal of hyaluronan, chondroitin sulphate/dermatan sulphate and DNA appears to be $>100 \%$ of the total pressure. This phenomenon can be explained by research conducted by Dick (Dick 1966) and Laurent and Ogston (Laurent \& Ogston 1963). The former showed that in non-ideal solutions such as follicular fluid, solution - solvent interactions occur and result in osmotic potentials greater or less than that predicted by the Van't Hoff Equation (Van't-Hoff 1887). The result of this is that the contributions of hyaluronan, proteoglycans and collagens to the follicular fluid osmotic potential cannot be considered as mutually exclusive contributions, since each is known to interact with the other.

In summary, we have identified glycosaminoglycans and proteoglycans in follicular fluid that can exert osmotic pressure. These glycosaminoglycans and proteoglycans are too large, either individually or collectively, to freely diffuse from the follicles and may therefore contribute to accumulation of follicular fluid by exerting an osmotic potential within the antrum of the follicle.

\section{Acknowledgements}

The authors would like to thank the following for their generous donation of antibodies: Dr Bruce Caterson, Department of
Surgery, University of North Carolina at Chapel Hill, NC, Dr Larry Fisher, Bone Research Branch, National Institute of Dental Research, National Institutes of Health, Bethesda, MD, Drs Dieter Zimmermann and Maria Teresa Dours-Zimmermann, Department of Pathology, University of Zurich, Zurich, Switzerland, Dr Anne Underwood, CSIRO Molecular Science, North Ryde, NSW, Australia. The authors would also like to thank Helen Irving-Rodgers of The University of Adelaide for her help with tissue health assessment, Peter Milburn of The Australian National University for the sequencing of the collagenase I sensitive proteins and Dr Gail Risbridger of the Monash Institute of Reproduction and Development. This research was supported by: National Health and Medical Research Council of Australia, the Dora Lush Scholarship from NHMRC (to HGC), The Faculty of Health Sciences University of Adelaide, The Clive and Vera Ramaciotti Foundations, Pest Animal Control Cooperative Research Centre Postgraduate Scholarship (to HGC), Medicine International and Faculty Postgraduate Research Scholarship, Monash University and a Cardiovascular Research Centre PhD scholarship (to SAH).

\section{References}

Andersen MM, Kroll J, Byskov AG \& Faber M 1976 Protein composition in the fluid of individual bovine follicles. Journal of Reproduction and Fertility 48 109-118.

Andrade-Gordon P, Wang SY \& Strickland S 1992 Heparin-like activity in porcine follicular fluid and rat granulosa cells. Thrombosis Research 66 475-487.

Ax RL \& Ryan RJ 1979 FSH stimulation of 3H-glucosamineincorporation into proteoglycans by porcine granulosa cells in vitro. Journal of Clinical Endocrinology and Metabolism 49 646-648.

Bellin ME \& Ax RL 1987 Purification of glycosaminoglycans from bovine follicular fluid. Journal of Dairy Science 70 1913-1919.

Bellin ME, Ax RL, Laufer N, Tarlatzis BC, DeCherney AH, Feldberg D \& Haseltine FP 1986 Glycosaminoglycans in follicular fluid from women undergoing in vitro fertilization and their relationship to cumulus expansion, fertilization, and development. Fertility and Sterility 45 244-248.

Bellin ME, Lenz RW, Steadman LE \& Ax RL 1983 Proteoglycan production by bovine granulosa cells in vitro occurs in response to fsh. Molecular and Cellular Endocrinology 29 51-65.

Bellin ME, Veldhuis JD \& Ax RL 1987 Follicular fluid glycosaminoglycans inhibit degradation of low-density lipoproteins and progesterone production by porcine granulosa cells. Biology of Reproduction 37 1179-1184.

Blumenkrantz N \& Asboe-Hansen G 1973 New method for quantitative determination of uronic acids. Analytical Biochemistry 54 484-489.

Blumenkrantz N \& Asboe-Hansen G 1974 An automated quantitative assay for uronic acids. Biochemical Medicine 11 60-66.

Boushehri I, Yadav MC \& Meur SK 1996 Characteristics of proteoglycans of buffalo ovarian follicular fluid during maturation of follicles. Indian Journal of Biochemistry \& Biophysics 33 213-217.

Bradford MM 1976 A rapid and sensitive method for the quantitation of microgram quantities of protein utilizing the principle of protein-dye binding. Analytical Biochemistry 72 248-254.

Bushmeyer SM, Bellin ME, Brantmeier SA, Boehm SK, Kubajak CL \& Ax RL 1985 Relationships between bovine follicular fluid glycosaminoglycans and steroids. Endocrinology 117 879-885.

Camaioni A, Salustri A, Yanagishita M \& Hascall VC 1996 Proteoglycans and proteins in the extracellular matrix of mouse cumulus cell-oocyte complexes. Archives of Biochemistry and Biophysics 325 190-198. 
Carrette O, Nemade RV, Day AJ, Brickner A \& Larsen WJ 2001 TSG-6 is concentrated in the extracellular matrix of mouse cumulus oocyte complexes through hyaluronan and inter-alpha-inhibitor binding. Biology of Reproduction 65 301-308.

Caterson B, Baker JR, Christner JE, Lee Y \& Lentz M 1985 Monoclonal antibodies as probes for determining the microheterogeneity of the link proteins of cartilage proteoglycan. Journal of Biological Chemistry 260 11348-11356.

Chen L, Mao SJ \& Larsen WJ 1992 Identification of a factor in fetal bovine serum that stabilizes the cumulus extracellular matrix. A role for a member of the inter-alpha-trypsin inhibitor family. Journal of Biological Chemistry 267 12380-12386.

Chen L, Mao SJ, McLean LR, Powers RW \& Larsen WJ 1994 Proteins of the inter-alpha-trypsin inhibitor family stabilize the cumulus extracellular matrix through their direct binding with hyaluronic acid. Journal of Biological Chemistry 269 28282-28287.

Chen L, Russell PT \& Larsen WJ 1993 Functional significance of cumulus expansion in the mouse: roles for the preovulatory synthesis of hyaluronic acid within the cumulus mass. Molecular Reproduction and Development 34 87-93.

Chen L, Zhang H, Powers RW, Russell PT \& Larsen WJ 1996 Covalent linkage between proteins of the inter-alpha-inhibitor family and hyaluronic acid is mediated by a factor produced by granulosa cells. Journal of Biological Chemistry 271 19409-19414.

Comper WD \& Laurent TC 1978 Physiological function of connective tissue polysaccharides. Physiological Reviews 58 255-315.

Coucouvanis E \& Martin GR 1995 Signals for death and survival: a twostep mechanism for cavitation in the vertebrate embryo. Cell $\mathbf{8 3}$ 279-287.

Coucouvanis E \& Martin GR 1999 BMP signaling plays a role in visceral endoderm differentiation and cavitation in the early mouse embryo. Development 126 535-546.

Edwards RG 1974 Follicular fluid. Journal of Reproduction and Fertility 37 189-219.

Eppig JJ \& Ward-Bailey PF 1984 Sulfated glycosaminoglycans inhibit hyaluronic acid synthesizing activity in mouse cumuli oophori. Experimental Cell Research 150 459-465.

Eriksen GV, Carlstedt I, Morgelin M, Uldbjerg N \& Malmstrom A 1999 Isolation and characterization of proteoglycans from human follicular fluid. The Biochemical Journal 340 613-620.

Eriksen GV, Malmstrom A \& Uldbjerg N 1997 Human follicular fluid proteoglycans in relation to in vitro fertilization. Fertility and Sterility $68791-798$.

Grimek HJ, Bellin ME \& Ax RL 1984 Characteristics of proteoglycans isolated from small and large bovine ovarian follicles. Biology of Reproduction 30 397-409.

Gu WY, Lai WM \& Mow VC 1993 Transport of fluid and ions through a porous-permeable charged-hydrated tissue, and streaming potential data on normal bovine articular cartilage. Journal of Biomechanics 26 709-723.

Hess KA, Chen L \& Larsen WJ 1999 Inter-alpha-inhibitor binding to hyaluronan in the cumulus extracellular matrix is required for optimal ovulation and development of mouse oocytes. Biology of Reproduction 61 436-443.

Hirashima Y, Kobayashi H, Gotoh J \& Terao T 1997 Inter-alpha-trypsin inhibitor is concentrated in the pericellular environment of mouse granulosa cells through hyaluronan-binding. European Journal of Obstetrics, Gynecology and Reproductive Biology 73 79-84.

Irving-Rodgers HF, van Wezel IL, Mussard ML, Kinder JE \& Rodgers RJ 2001 Atresia revisited: two basic patterns of atresia of bovine antral follicles. Reproduction 122 761-775.

Irving-Rodgers HF, Harland ML \& Rodgers RJ 2004 A novel basal lamina matrix of the stratified epithelium of the ovarian follicle. Matrix Biology 23 207-217.

Ishihara H, Warensjo K, Roberts S \& Urban JP 1997 Proteoglycan synthesis in the intervertebral disk nucleus: the role of extracellular osmolality. American Journal of Physiology 272 C1499-C1506.
Jackson DG 2003 The lymphatics revisited: new perspectives from the hyaluronan receptor LYVE-1. Trends in Cardiovascular Medicine $131-7$.

Jones S, Daley DT, Luscombe NM, Berman HM, Thornton JM \& van Heyningen P 2001 Protein-RNA interactions: a structural analysis. Protein-DNA interactions: a structural analysis. Nucleic Acids Research 29 943-954.

Keikhoffer W, Holmer GJ \& Peckham B 1962 Some chemical characteristics of ovarian and parovarian cystic fluids. Obstetrics \& Gynecology 20 471-483.

Kimura N, Konno Y, Miyoshi K, Matsumoto H \& Sato E 2002 Expression of hyaluronan synthases and CD44 messenger RNAs in porcine cumulus-oocyte complexes during in vitro maturation. Biology of Reproduction 66 707-717.

Kobayashi H, Sun GW, Hirashima Y \& Terao T 1999 Identification of link protein during follicle development and cumulus cell cultures in rats. Endocrinology 140 3835-3842.

Kovach IS 1995 The importance of polysaccharide configurational entropy in determining the osmotic swelling pressure of concentrated proteoglycan solution and the bulk compressive modulus of articular cartilage. Biophysical Chemistry 53 181-187.

Laemmli UK 1970 Cleavage of structural proteins during the assembly of the head of bacteriophage T4. Nature 227 680-685.

Laurent C, Hellstrom S, Engstrom-Laurent A, Wells AF \& Bergh A 1995 Localization and quantity of hyaluronan in urogenital organs of male and female rats. Cell and Tissue Research 279 241-248.

Laurent TC 1987 Biochemistry of hyaluronan. Acta Oto-laryngologica. Supplementum 442 7-24.

Laurent TC \& Ogston AG 1963 The Interaction between polysaccharides and other macromolecules, 4 . The osmotic pressure of mixtures of serum albumin and hyaluronic acid. Biochemistry 89 249-253.

Lemire JM, Merrilees MJ, Braun KR \& Wight TN 2002 Overexpression of the V3 variant of versican alters arterial smooth muscle cell adhesion, migration, and proliferation in vitro. Journal of Cellular Physiology 190 38-45.

McArthur ME, Irving-Rodgers HF, Byers S \& Rodgers RJ 2000 Identification and immunolocalization of decorin, versican, perlecan, nidogen, and chondroitin sulfate proteoglycans in bovine smallantral ovarian follicles. Biology of Reproduction 63 913-924.

Manarang-Pangan S \& Menge AC 1971 Immunologic studies on human follicular fluid. Fertility and Sterility 22 367-372.

Mandel-Gutfreund Y, Schueler O \& Margalit H 1995 Comprehensive analysis of hydrogen bonds in regulatory protein DNA-complexes: in search of common principles. Journal of Molecular Biology 253 370-382.

Meyer GT, Matthias LJ, Noack L, Vadas MA \& Gamble JR 1997 Lumen formation during angiogenesis in vitro involves phagocytic activity, formation and secretion of vacuoles, cell death, and capillary tube remodelling by different populations of endothelial cells. Anatomical Record 249 327-340.

Nagyova E, Camaioni A, Prochazka R \& Salustri A 2004 Covalent transfer of heavy chains of inter-al pha-trypsin inhibitor family proteins to hyaluronan in in vivo and in vitro expanded porcine oocytecumulus complexes. Biology of Reproduction 71 1838-1843.

Parillo F, Stradaioli G \& Verini-Supplizi A 1998 Glycoconjugates in small antral ovarian follicles of the river buffalo (Bubalus bubalis L.). Acta Histochemica 100 229-243.

Perloff WH, Schultz J, Farris EJ \& Balin H 1955 Some aspects of the chemical nature of human ovarian follicular fluid. Fertility and Sterility 6 11-16.

Princivalle M, Hasan S, Hosseini G \& de Agostini Al 2001 Anticoagulant heparan sulfate proteoglycans expression in the rat ovary peaks in preovulatory granulosa cells. Glycobiology 11 183-194.

Reyes R, Carranco A, Hernandez O, Rosado A, Merchant H \& Delgado NM 1984 Glycosamineglycan sulfate as acrosomal reactioninducing factor of follicular fluid. Archives of Andrology 12 203-209.

Rodgers RJ, Irving-Rodgers HF, van Wezel IL, Krupa M \& Lavranos TC 2001 Dynamics of the membrana granulosa during expansion of the 
ovarian follicular antrum. Molecular and Cellular Endocrinology $17141-48$.

Rosengren BI, Carlsson O \& Rippe B 2001 Hyaluronan and peritoneal ultrafiltration: a test of the "filter-cake" hypothesis. American Journal of Kidney Diseases (Online) 37 1277-1285.

Rouet P, Daveau M \& Salier JP 1992 Electrophoretic pattern of the interalpha-inhibitor family proteins in human serum, characterized by chain-specific antibodies. Biological Chemistry Hoppe Seyler 373 1019-1024.

Rugg MS, Willis AC, Mukhopadhyay D, Hascall VC, Fries E, Fulop C, Milner CM \& Day AJ 2005 Characterization of complexes formed between TSG- 6 and inter-alpha-inhibitor that act as intermediates in the covalent transfer of heavy chains onto hyaluronan. Journal of Biological Chemistry $28025674-25686$.

Russell DL, Ochsner SA, Hsieh M, Mulders S \& Richards JS 2003 Hormone-regulated expression and localization of versican in the rodent ovary. Endocrinology 144 1020-1031.

Saito H, Kaneko T, Takahashi T, Kawachiya S, Saito T \& Hiroi M 2000 Hyaluronan in follicular fluids and fertilization of oocytes. Fertility and Sterility 74 1148-1152.

Salier JP, Diarra-Mehrpour M, Sesboue R, Bourguignon J, Benarous R, Ohkubo I, Kurachi S, Kurachi K \& Martin JP 1987 Isolation and characterization of cDNAs encoding the heavy chain of human interalpha-trypsin inhibitor (I alpha TI): unambiguous evidence for multipolypeptide chain structure of I alpha TI. PNAS 84 8272-8276.

Sato E, Ishibashi T \& Koide SS 1987 Prevention of spontaneous degeneration of mouse oocytes in culture by ovarian glycosaminoglycans. Biology of Reproduction 37 371-376.

Sato E, Kawamura N \& Ishibashi T 1988 Chemicals influencing maturation, activation, and degeneration of bovine oocytes in culture. Journal of Dairy Science 71 3482-3488.

Schmalfeldt M, Dours-Zimmermann MT, Winterhalter KH \& Zimmermann DR 1998 Versican V2 is a major extracellular matrix component of the mature bovine brain. Journal of Biological Chemistry 273 15758-15764.

Schoenfelder M \& Einspanier R 2003 Expression of hyaluronan synthases and corresponding hyaluronan receptors is differentially regulated during oocyte maturation in cattle. Biology of Reproduction 69 269-277.

Shalgi R, Kraicer P, Rimon A, Pinto M \& Soferman N 1973 Proteins of human follicular fluid: the blood-follicle barrier. Fertility and Sterility 24 429-434.

Shalgi R, Kraicer PF \& Soferman N 1972 Gases and electrolytes of human follicular fluid. Journal of Reproduction and Fertility $\mathbf{2 8}$ 335-340.

Shimada H, Kasakura S, Shiotani M, Nakamura K, Ikeuchi M, Hoshino T, Komatsu T, Ihara Y, Sohma M, Maeda Y, et al. 2001 Hypocoagulable state of human preovulatory ovarian follicular fluid: role of sulfated proteoglycan and tissue factor pathway inhibitor in the fluid. Biology of Reproduction 64 1739-1745.

Tadano Y \& Yamada K 1978 The histochemistry of complex carbohydrates in the ovarian follicles of adult mice. Histochemistry 57 203-215.
Tertemiz F, Kayisli UA, Arici A \& Demir R 2005 Apoptosis contributes to vascular lumen formation and vascular branching in human placental vasculogenesis. Biology of Reproduction 72 727-735.

Towbin H, Staehelin T \& Gordon J 1979 Electrophoretic transfer of proteins from polyacrylamide gels to nitrocellulose sheets: procedure and some applications. PNAS 76 4350-4354.

Tsuiki A, Preyer J \& Hung TT 1988 Fibronectin and glycosaminoglycans in human preovulatory follicular fluid and their correlation to follicular maturation. Human Reproduction 3 425-429.

Turner RE, Lin PY \& Cowman MK 1988 Self-association of hyaluronate segments in aqueous $\mathrm{NaCl}$ solution. Archives of Biochemistry and Biophysics 265 484-495.

Van Wezel IL, Dharmarajan AM, Lavranos TC \& Rodgers RJ 1999a Evidence for alternative pathways of granulosa cell death in healthy and slightly atretic bovine antral follicles. Endocrinology 140 2602-2612.

van Wezel IL, Krupa M \& Rodgers RJ 1999b Development of the membrana granulosa of bovine antral follicles: structure, location of mitosis and pyknosis, and immunolocalization of involucrin and vimentin. Reproduction, Fertility and Development 11 37-48.

Vanderboom RJ, Carroll DJ, Bellin ME, Schneider DK, Miller DJ, Grummer RR \& Ax RL 1989 Binding of bovine follicular fluid glycosaminoglycans to fibronectin, laminin and low-density lipoproteins. Journal of Reproduction and Fertility 87 81-87.

Van't-Hoff HH 1887 The role of osmotic pressure in the analogy between solutions and gasses. Zeitschrift fur physikalische Chemie $\mathbf{1}$ 481-508.

Varner DD, Forrest DW, Fuentes F, Taylor TS, Hooper RN, Brinsko SP \& Blanchard TL 1991 Measurements of glycosaminoglycans in follicular, oviductal and uterine fluids of mares. Journal of Reproduction and Fertility Supplement 44 297-306.

Wise T \& Maurer RR 1994 Follicular development, oocyte viability and recovery in relation to follicular steroids, prolactin and glycosaminoglycans throughout the estrous period in superovulated heifers with a normal LH surge, no detectable LH surge, and progestin inhibition of LH surge. Domestic Animal Endocrinology 11 35-58.

Yanagishita M, Hascall VC \& Rodbard D 1981 Biosynthesis of proteoglycans by rat granuloma cells cultured in vitro: modulation by gonadotropins, steroid hormones, prostaglandins, and a cyclic nucleotide. Endocrinology 109 1641-1649.

Zamparo O \& Comper WD 1989 Hydraulic conductivity of chondroitin sulfate proteoglycan solutions. Archives of Biochemistry and Biophysics 274 259-269.

Received 10 September 2005

First decision 15 November 2005

Revised manuscript received 8 January 2006

Accepted 13 February 2006 